\title{
Newsletter $N^{\circ}$ 6/2009
}

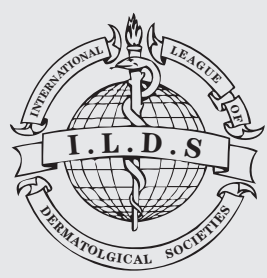

\section{Contents}

22nd World Congress of Dermatology

- Letter from Seoul

23rd World Congress of Dermatology

- Letter from Istanbul

- Letter from Rome

- Letter from Vancouver

Letter from Co-Chairs of the WHO/ILDS Dermatology TAG for ICD11

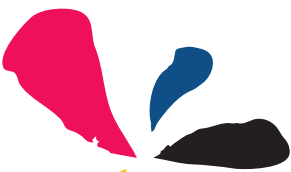

22nd

World Congress of

Dermatology

Seoul 2011

\section{Letter from Seoul}

1. Local Organizing Committee: Commencing Full Operation

Despite the hard work some key local Organizing Committee members have been engaged in to prepare for the 22nd WCD, many local members have, until recently, been thinking that the congress is a long way off. However, the program committee meeting in Berlin in February brought about a general realization that the Congress is really only two years away. To further spread this anticipation to each individual, a local Organizing Committee Meeting was held on March 17, 2009 at COEX, Seoul - the venue for the 22nd WCD. About 60 Korean Organizing Committee members gathered together and reaffirmed their commitment to the success of the 22nd World Congress of Dermatology.
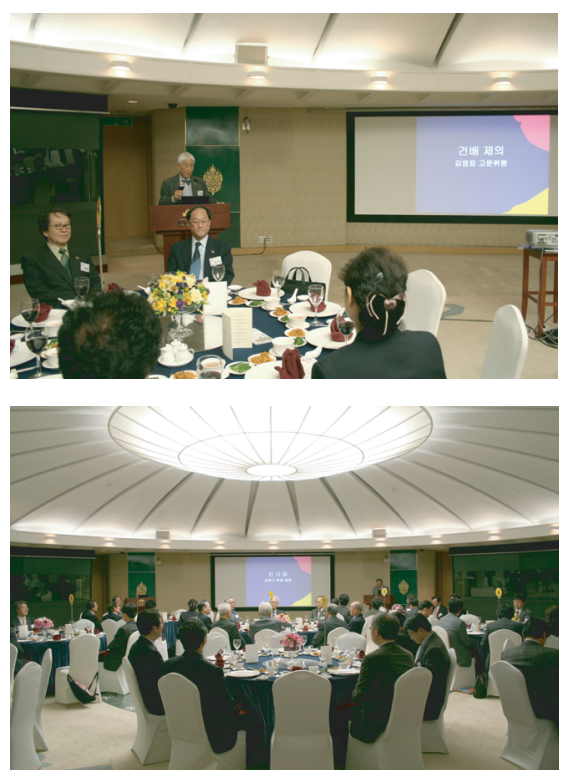

2. First Announcement: Distribution Actively Supported by Many ILDS Member Societies

As of mid-April 2009, we have received positive confirmation from 42 societies across 38 countries of their willingness to cooperate to promote the 22nd World Congress of Dermatology by distributing the first announcement to their members. The first announcement has already been delivered to these member societies, except to those societies that have offered to contribute by directly sending us their member databases.

In addition, the ILDS has formally asked each member society to distribute the announcement electronically. Those member societies who have not yet distributed the announcements are asked to make a request to the local Organizing Committee (wcd2011@koconex.com).

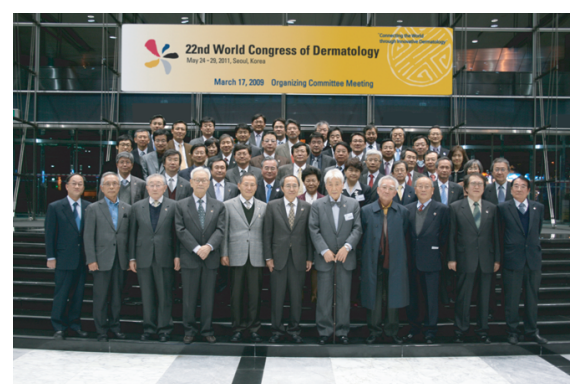

\section{Public Relations}

Prof. Hee Chul Eun, President of the local Organizing Committee, will participate as an invited speaker at the 15th Chinese Annual Congress of Dermatology and Venerology, which will be held from June 13 to 16, 2009 in Tianjin, China. The Chinese Society of Dermatology is one of the biggest societies in the world. The Organizing Committee of the conference kindly offered us a booth for the promotion of the 22nd World Congress of Dermatology. He will also attend the 4th Joint Meeting of the Japanese Dermatological Association and the Australian College of Dermatologists in Sapporo, Japan, from July 10 to 12 , as an invited speaker.

The 108th Japanese Dermatological Association (JDA) Annual Meeting was held in Fukuoka, Japan from April 24 to 26, 2009, which more than 4,000 Japanese members attended. The Organizing Committee of the 108th JDA kindly provided the local Organizing Committee a promotion booth for the 22nd WCD. Professor Young Suck Ro, Chairman of the Promotion Committee, attended the meeting to promote the 22 nd WCD.

\section{Official Airline}

Korean Air was designated as the official airline for the congress. We expect to be able to provide better prices and more flight routes for the attendees through this partnership. 
Societies that participated in the distribution of the first announcement of the 22nd World Congress of Dermatology

\begin{tabular}{|c|c|c|c|}
\hline No & Country & Name of Society & Number Delivered \\
\hline 1 & Argentina & Argentine Association of Dermatology & Online distribution \\
\hline 2 & Australia & The Australasian College of Dermatologists & 500 \\
\hline 3 & Belgium & Royal Belgian Society for Dermatology \& Venereology & Online distribution \\
\hline 4 & Brazil & Brazilian Society of Dermatology & 5,016 \\
\hline 5 & Canada & Canadian Dermatology Association & 650 \\
\hline 6 & China & Chinese Society of Dermatology & 1,500 \\
\hline 7 & Cyprus & Cyprus Society of Dermatology & 72 \\
\hline 8 & Czech Republic & Czech Dermatovenerology Society & 800 \\
\hline 9 & Denmark & Danish Dermatological Society & 150 \\
\hline 10 & Ecuador & Ecuadorian Society of Dermatology & 30 \\
\hline 11 & El Salvador & Salvadorian Society of Dermatology & 28 \\
\hline 12 & Finland & Finnish Dermatological Society & 350 \\
\hline 13 & France & French Society of Dermatology & Introduced in their newsletter \\
\hline 14 & Germany & German Dermatological Society & Promised to provide database \\
\hline 15 & Greece & The Hellenic Society of Dermatology \& Venereology & 1,000 \\
\hline 16 & India & Indian Association of Dermatologists, Venerologists and Leprologists & 5,500 \\
\hline 17 & India & Cosmetology Society of India & 1,000 \\
\hline 18 & Iran & Iranian Society of Dermatology & 700 \\
\hline 19 & Israel & Israel Society of Dermatology \& Venereology & 350 \\
\hline 20 & Italy & Association of Italian Clinical Dermatologists & Introduced in their newsletter \\
\hline 21 & Japan & Japanese Dermatological Association & 12,000 \\
\hline 22 & Korea & Korean Dermatological Association & 1,700 \\
\hline 23 & Latvia & Association of Dermato-Venerologists of Latvia & 160 \\
\hline 24 & Malta & Maltese Association of Dermatology & 15 \\
\hline 25 & Mexico & Mexican Society of Dermatologic Surgery \& Oncology & 400 \\
\hline 26 & Mexico & Mexican Society of Dermatology & Promised to provide database \\
\hline 27 & Norway & Norwegian Society of Dermatology & Uploading on homepage \\
\hline 28 & Pakistan & Association of Bangkok Alumni of Dermatology - Pakistan & 10 \\
\hline 29 & Philippines & Philippine Dermatological Society & 800 \\
\hline 30 & Poland & Polish Association of Dermatology & 2,200 \\
\hline 31 & Romania & Romanian Dermatological society & 500 \\
\hline 32 & Slovakia & Slovak Dermatovenereological Society & 460 \\
\hline 33 & South Africa & Dermatological Society of South Africa & 170 \\
\hline 34 & Sri Lanka & Sri Lanka College of Dermatologists & 100 \\
\hline 35 & Sweden & Swedish Society for Dermatology and Venereology & Promised to provide database \\
\hline 36 & Switzerland & Swiss Society of Dermatology \& Venerology & Uploading on homepage \\
\hline 37 & Syria & Syrian Arab Society of Dermatology & 350 \\
\hline 38 & Tunisia & Tunisian Society of Dermatology and Venereology & 250 \\
\hline 39 & Turkey & Turkish Society of Dermatology & 1,700 \\
\hline 40 & Turkey & Society of Dermatoveneology & 1,600 \\
\hline 41 & Venezuela & Venezuelan Society of Dermatology \& Dermatologic Surgery & 400 \\
\hline \multirow[t]{2}{*}{42} & International & Women's Dermatologic Society & Online distribution \\
\hline & & Total (42 Societies from 38 Countries out of the 100 Societies from 71 Countries) & 40,461 \\
\hline
\end{tabular}




\section{3rd World Congress of Dermatology}

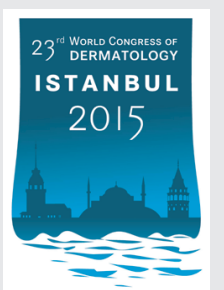

\section{Letter from Istanbul}

The World Congress of Dermatology is one of the most exciting events for dermatologists worldwide. This important organization has been active all over the world throughout its history. We hope that the 23rd World Congress will be held in Istanbul, where two continents meet. Dermatology \& Venereology has a long and distinguished tradition in our country and has been enhanced by many different scientists during its history. The most famous Turkish dermatologist was Hulusi Behçet and the Turkish dermatology family contains nearly 2,000 physicians now.

Istanbul is the intersection point of different cultures, traditions and one of the most popular destinations for globe-trotters. The newly-restored convention centre, conveniently located in the heart of the city, has been chosen as the meeting venue of the 23rd World Congress. We sincerely believe that Turkish hospitality, supported by the experienced organisation committee, will satisfy a huge number of participants, and we are confident that the dermatologists will never forget this fabulous and scientific congress.

As the Turkish Society of Dermatology, it gives us great pleasure to be among the Nominees of the World Congress Organisers. We hope that we will have the honour of welcoming you to Istanbul.

\section{Letter from
Rome}

XXIIITWCDROME2015
WORID CONGRESS OF DERMATOLOGY Why Italy?

Italy is the cradle of

modern medicine, and Bologna and Padova were the first western universities to teach medicine and fundamental in medical practice. Vesalio and Paracelso, even if not born in Italy, started their academic career in our country. Many Italian's names are very familiar to dermatologists worldwide such as Malpighi, Mibelli, Maiocchi, Crosti and Gianotti.

\section{Why Rome?}

Rome, the cradle of Western civilization, was instrumental in shaping so many fundamental aspects of our modern life. Its history and legacy are unparalleled. More artwork is to be enjoyed in Rome than perhaps in the whole rest of the world, and its museums, exhibitions and lifestyle make it unique.

We can offer not only a unique opportunity to enjoy Rome but also to visit before or after the meeting all the Italian beauties, with options for every budget and specific interest.
Hotels

Rome offers a wide range of accommodation from fivestar to low budget hotels, all renovated and well connected with Nuova Fiera di Roma by urban railway. More than 2000 rooms are located 5-10 minutes distant from the venue and about $20 \mathrm{~min}$ utes from downtown, by public transport; another 2000 rooms are at 10-15 minutes from Nuova Fiera di Roma, closer to the city centre. We can also offer very low budget accommodations in special guest houses: 'peregrin houses'.

\section{Congress Venue}

The venue of Meeting will be the newly built Nuova Fiera di Roma conference and exhibition centre, located west of Rome. This venue is a strategic location: less than $5 \mathrm{~km}$ from Leonardo da Vinci Airport (Fiumicino), well connected by public bus and by taxi; three turnoffs from the near two motorways. The railway connects the congress venue to downtown in 20 minutes.

With 14 pavilions, equipped with the most advanced technologies $(390,000 \mathrm{sq})$, Nuova Fiera diRoma is a flexible and multifunctional area, used for important international Meeting and Events.

\section{President Sergio Chimenti}

General-Secretary Antonella Tosti

Honorary President Alberto Giannetti

Scientific Secretary Carlo Gelmetti

\section{www.wcd2015rome.com}

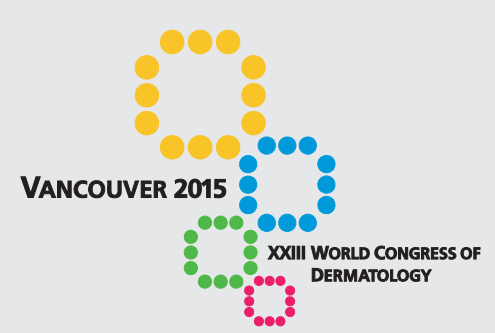

\section{Letter from Vancouver}

Canadian Dermatology Association and the Vancouver 2015 World Congress of Dermatology Bid

www.derm2015.org

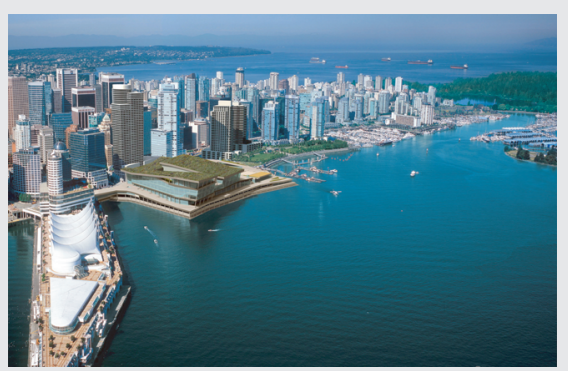

The Canadian Dermatology Association's World Congress of Dermatology Bid for Vancouver 2015 is well underway. Under the leadership of Drs. Jerry Shapiro, Harvey Lui and Larry Warshawski, a WCD Bid Committee of the Canadian Dermatology As- sociation (CDA) has been established with members from across Canada. Tourism Vancouver and the Vancouver Convention Centre are providing their full support, energy and expertise to our bid preparations.

We are delighted that many of our ILDS friends and colleagues were able to attend the Canadian Dermatology Association reception and the University of British Columbia Dermatology reception, held in March during the American Academy of Dermatology annual meeting in San Francisco. We also met many other international delegates and friends who visited our exhibit booth in the AAD Exhibit Hall.

\section{Wood, Windows and Wow!}

The new state-of-the-art Vancouver Convention Centre was officially opened in April 2009. This building, which is an extension of the existing convention centre, is truly a stunning piece of architecture, Canadian flavor and magnificent vistas. Those who have visited the expanded west building of the Convention Centre have described it as Wood, Windows and WOW! From the living roof, featuring over 300 species of West Coast fauna to the lumberyard look of the interior foyer to the spectacular ballroom with floor to ceiling windows that provide a view of ocean, city, parkland and mountains - it's impossible not to be wowed!

With the completed expansion, the Vancouver Convention Centre has now tripled in size to cover 1.1 million square feet (four city blocks) for a combined total of 473,523 square feet of pre-function, meeting, exhibition and ballroom space. The expanded centre focuses on a commitment to green technology including a 'living roof', seawater heating and cooling, on-site water treatment and even fish habitat built into the foundation.

Of course the other big event we are all preparing for in Vancouver is the Winter Olympics next Feburuary 2010. Our new convention centre will serve as the international broadcast centre during the Olympics. To get a preview of Vancouver all you have to do is tune in your TV next February or better yet, come and catch all the live action in person.

Our team looks forward to sharing our unique Canadian hospitality and presenting our bid to host the 2015 World Congress in Vancouver when the global dermatology community next meets in Seoul in 2011.

Jerry Shapiro, President Harvey Lui, Secretary-General Larry Warshawski, Bid Director, CDA Liaison Vancouver 2015 World Congress of Dermatology Bid Committee 


\section{Letter from} Co-Chairs of the WHO/ILDS Dermatology TAG for ICD11

\section{Dermatology and the International Classification of Diseases}

Michael Weichenthal, University of Kiel, Germany Robert Chalmers, University of Manchester, UK

The World Health Organisation (WHO) has recently embarked on an ambitious programme to update the International Classification of Diseases (ICD). The 11 th Revision (ICD-11) is scheduled for publication in 2014. WHO has recognised that there are significant shortcomings in the methods used to produce previous updates and is now intent on encouraging much wider consultation. Furthermore it plans a much more ambitious product than a mere hierarchical list of diagnoses (see Box 1).

\begin{tabular}{|l|}
\hline Box 1 Extract from ICD Revision Proposals, \\
WHO 2008 \\
\hline The ICD revision process aims to: \\
- Develop a coherent, internally consistent, \\
and reliable international classification \\
system for: \\
- Coding mortality (causes of death) \\
- Coding morbidity (diseases and related \\
health problems) \\
- Use in different settings (e.g. primary care, \\
clinical care) and for different purposes \\
(research, public health, quality assurance) \\
- Establish ICD-11 as a user-friendly and \\
scientifically credible classification that is con- \\
tinuously updated with the use of modern \\
knowledge management and sharing meth- \\
ods \\
Provide evidence-based linking of each deci- \\
sion and category to the relevant scientific \\
literature available as a dynamic classification \\
system that will be regularly
\end{tabular}

WHO has identified a limited number of specialties where it has recognised that there has been dissatisfaction with the current versions of ICD and it has invited them to participate in the revision process. As the only dermatological body with official links to WHO, the International League of Dermatological Societies was approached by WHO in September 2008 and accepted its invitation to form a Dermatology Topic Advisory Group (TAG). This means that dermatology will now be represented directly at the ICD Revision Steering Group in Geneva during the process of drafting a comprehensive alpha version of $I C D-11$. This is scheduled to take place between September 2009 and May 2010. Dermatology is one of only a small number of specialties with direct representation at this level. Most medical and surgical specialties are subsumed into more general TAGs such as Internal Medicine, Oncology or Infectious Disease.

The creation of the Dermatology TAG means that there is now a once in a generation opportunity to address the many deficiencies in the current classification of skin disease. These will be familiar to many dermatologists, whether they use $I C D-9$ or $I C D-10$. ICD-10 thus includes bizarrely detailed diagnostic concepts (e.g. anetoderma of Schweninger-Buzzi and anetoderma of Jadassohn-Pelizzari) but omits many important and common diagnostic entities. As a striking example, it fails to distinguish between our two commonest cancers, basal cell carcinoma and squamous cell carcinoma of the skin.

\begin{tabular}{|c|c|}
\hline $\begin{array}{l}\text { Box } 2 \text { Dermatology Topi } \\
\text { Membership }\end{array}$ & c Advisory Group \\
\hline Co-chairs & \\
\hline DrRobert Chalmers & $\begin{array}{l}\text { University of } \\
\text { Manchester, UK }\end{array}$ \\
\hline DrMichael Weichenthal & $\begin{array}{l}\text { University of Kiel, } \\
\text { Germany }\end{array}$ \\
\hline Members & \\
\hline Dr Takeshi Kono & $\begin{array}{l}\text { Kansai Rosai Hospital, } \\
\text { Amagasaki, Japan }\end{array}$ \\
\hline Professor Alfons Krol & $\begin{array}{l}\text { Oregon Health \& } \\
\text { Science University, } \\
\text { Portland OR, USA }\end{array}$ \\
\hline Professor Mourad Mokni & $\begin{array}{l}\text { University Hospital, } \\
\text { Tunis, Tunisia }\end{array}$ \\
\hline Professor Luigi Naldi & $\begin{array}{l}\text { University of Bergamo, } \\
\text { Italy }\end{array}$ \\
\hline Dr Edith Nkechi Nnoruka & $\begin{array}{l}\text { University of Nigeria, } \\
\text { Enugu, Nigeria }\end{array}$ \\
\hline Dr Pablo Fernández Peñas & $\begin{array}{l}\text { Sniversity of Sydney, } \\
\text { Australia }\end{array}$ \\
\hline Professor Mark Pittelkow I & $\begin{array}{l}\text { Mayo Clinic, Rochester } \\
\text { MN, USA }\end{array}$ \\
\hline Professor Peter Soyer & $\begin{array}{l}\text { University of } \\
\text { Queensland, Australia }\end{array}$ \\
\hline
\end{tabular}

The ILDS Board has invited the two of us to co-chair the Dermatology TAG. We have both been involved for many years with the development of dermatological disease classification, MW with the German Dermatologischer Diagnosenkatalog (based on ICD10) and RC with the British Association of Dermatologists' Index of Dermatological Diagnoses, the generic healthcare terminologies, Clinical Terms and SNOMED CT, and more recently as adviser to the US Dermatology Lexicon Project (DermLex). Over the past few months, dermatologists representing a wide range of interests and geographical regions have agreed to join the TAG (see Box 2) and over the next few months they will be convening Expert Working Groups to address different subspecialty areas of interest such as paediatric dermatology, dermatological oncology and sexually transmitted diseases.

A look at Box 1 will demonstrate that WHO intends to produce a much more sophisticated product than $I C D-10$. ICD-11 will be available in a simple format similar to $/ C D-10$ but the full version will look more like Wikipedia ${ }^{\circledR}$ : each disease concept will be much more fully defined and described, including a short definition, the terms used to describe it not only in English but also in other major global languages, its hierarchical relationships to other disease concepts, its mapping to other terminologies such as SNOMED CT, and links to relevant reference works from which more detailed information can be obtained.

$\mathrm{RC}$ has agreed to act as Managing Editor for the Dermatology TAG at WHO during the alpha drafting process. This will involve not only coordinating the incorporation of dermatological diagnoses into the alpha version of $I C D-11$ but also liaising with other TAGs and their Expert Working Groups over diagnostic concepts where there may be shared ownership (e.g. infectious diseases of the skin, connective tissue disease, skin cancer).

The task ahead will be challenging. We do, however, intend to make full use of work already done by dermatologists around the globe. The goal of developing a standardised international reference terminology for skin disease had already been discussed at an informal forum at the World Congress of Dermatology in Buenos Aires in 2007. We feel that there are two reasons why it is desirable that ILDS should use the current opportunity to produce an independent but linked terminology. Firstly, ICD-11 will not be released until 2014 and may not be in widespread use until 2015 or 2016 . Secondly, there are constraints on the ways in which terms of relevance to dermatologists can be presented in ICD. The President of ILDS, Professor JeanHilaire Saurat, and we feel that the League should use the opportunity of the ICD drafting process to develop an independently owned International Dermatological Disease Ontology* which could be published at an earlier date, could represent skin disease in a fashion which makes sense for dermatologists but which would nevertheless maintain precise mappings and links to the equivalent content in ICD. The opportunity afforded by the production of the alpha version of $I C D-11$ during this year and the next should be seized and used to develop this pari passu with $I C D-11$. We are grateful to ILDS for its support of these ventures.

\section{Robert Chalmers, Michael Weichenthal May 2009}

*Ontology: a complete representation of what entities exist or can be said to exist, and how such entities can be grouped, related within a hierarchy, and subdivided according to similarities and differences.

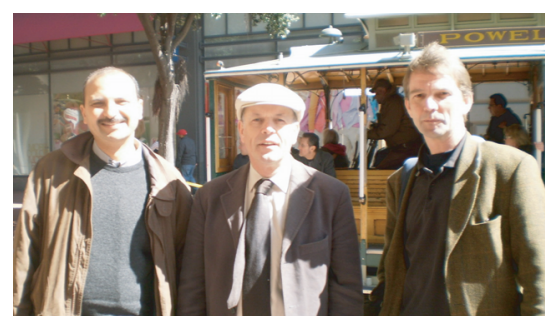

Some members of the ICDTAG at their first meeting in San Francisco in March this year. From I to r Professor Mourad Mokni, Co-Chairs Dr. Robert Chalmers and Dr. Michael Weichenthal. 